\title{
IMPLEMENTASI PENGGUNAAN DANA DESA TAHUN ANGGARAN 2019 BERDASARKAN PERMENDES NOMOR 16 TAHUN 2018 TENTANG PRIOROTAS PENGGUNAAN DANA DESA TAHUN 2019 DI DESA KANAMIT BARAT KECAMATAN MALIKU KABUPATEN PULANG PISAU
}

\author{
IMPLEMENTATION OF THE USE OF VILLAGE YEAR 2019 BUDGET BASED ON PERMENDES NUMBER I6 \\ YEAR 2018 REGARDING THE PRIOROTAS OF THE USE OF 2019 VILLAGE FUNDS IN KANAMIT BARAT \\ KECAMATAN MALIKU DISTRICT, PULANG PISAU PISAU PISAU PISAU PISAU PISAU
}

Hambowo Sulistyo Putro

Nurul Hikmah Kartini

\begin{abstract}
Abstrak
Penelitian ini mengangkat judul "Implementasi Penggunaan Dana Desa untuk Tahun Anggaran 2019 Berdasarkan Peraturan Menteri Desa No. 16 Tahun 2018 Tentang Prioritas Penggunaan Dana Desa pada 2019 Di Desa Kanamit Barat, Distrik Maliku, Kabupaten Pulang Pisau"

Secara umum, penelitian ini dimaksudkan untuk mengetahui apa saja realisasi penggunaan dana desa pada tahun 2019 dengan menggunakan penelitian dasar Peraturan Menter Desa Nomor 16 Tahun 2018 Tentang Prioritas Penggunaan Dana Desa pada tahun 2019 dengan menggunakan analisis kualitatif yaitu metode pengumpulan bahan berupa observasi, dokumentasi kemudian wawancara dengan informan atau informan secara verbal.

Berdasarkan bahan yang diolah dari hasil penelitian ditemukan dua kesimpulan, Yang pertama, berdasarkan Wawancara pertama dan Dokumentasi Penggunaan Dana Desa untuk Tahun Anggaran 2019 Di Desa Kanamit Barat, Kabupaten Maliku, Kabupaten Pulang Pisau untuk Desa Sektor Pembangunan, sebagian besar telah memenuhi ketentuan Peraturan Menteri Desa Nomor 16 Tahun 2018 Tentang Prioritas Penggunaan Dana Desa pada 2019 dan ada satu yang kurang tepat karena tidak menggunakan pola intensif tunai seperti Perogram. program pengembangan BTS Menara Mini Yang kedua, Penggunaan Dana Desa untuk Tahun Anggaran 2019 Di Desa Kanamit Barat, Kabupaten Maliku, Kabupaten Pulang Pisau untuk Bidang Pemberdayaan Masyarakat semuanya sesuai dengan ketentuan Peraturan Menteri Desa 16 tahun. 2018 Tentang Prioritas Penggunaan Dana Desa pada 2019.
\end{abstract}

\begin{abstract}
This research raises the title "Implementation of Village Funds Use for Fiscal Year 2019 Based on the Minister of Village Regulation No.16 of 2018 About Priority for the Use of Village Funds in 2019 In the West Kanamit Village, Maliku District, Pulang Pisau Regency"

In general, this research is intended to find out what the realization of the use of village funds in 2019 by using basic research Minister of Village Regulation No.16 of 2018 About Priority for the Use of Village Funds in 2019 by using qualitative analysis namely the method of material collection in the form of observation, documentation then interviews with informants or informants verbally.

Based on the material processed from the results of the study found two conclusions, The first, based on the first Interview and Documentation of the Use of Village Funds for Fiscal Year 2019 In the West Kanamit Village, Maliku District, Pulang Pisau Regency for the Village Development Sector, most have complied with the provisions on the Minister of Village Regulation No. 16 of 2018 About Priority for the Use of Village Funds in 2019 and there is one that is less appropriate because it does not use Cash-intensive patterns the Perogram is a Mini Tower BTS development program The second, Use of Village Funds for Fiscal Year 2019 In the West Kanamit Village, Maliku District, Pulang Pisau Regency for the Field of Community Empowerment everything is in accordance with the provisions on the Minister of Village

Regulation No.16 of 2018 About Priority for the Use of Village Funds in 2019.
\end{abstract}

Implementation, Village Funds, Pemerndes.
(C) 2020 The Authors. Published by Institute for Research and Community Services Universitas Muhammadiyah Palangkaraya. This is Open Access article under the CC-BY-SA License (http://creativecommons.org/licenses/by-sa/4.0/).

DOI: https://doi.org/10.33084/anterior.v18i2.456. 


\section{A. PENDAHULUAN}

Pembangunan Daerah adalah suatu kegiatan sistematik yang dilakukan untuk meningkatkan kesejahteraan dan kualitas hidup masyarakat desa. Pada era reformasi ini pemerintah menerapkan sebuah sistem yaitu sistem desentralisasi sesuai dengan Undang-Undang No.22 Tahun 1999 tentang Pemerintahan Daerah, dan Undang-Undang No.25 Tahun 1999 tentang Perimbangan Keuangan Pusat dan Daerah. Kedua undang- undang ini menjadi landasan hukum yang mengelola hubungan antara pihak pemerintah pusat dan pemerintah daerah dan menjadilandasan hukum penerapan sistem otonomi daerah di Indonesia. Kemudian Undang- Undang No. 25 Tahun 1999 menyebutkan bahwa adanya perluasan kewenangan pemerintah daerah dalam mengelola keuangan terutama dalam penerimaan (revenue) dan pengeluaran (expenditure).

Pemerintahan Desa menyelenggaraan urusan pemerintahan sekaligus memenuhi segala kepentingan masyarakat setempat dalam sistem pemerintahan Negara Kesatuan Republik Indonesia, seperti yang tertuang dalam Undang-Undang No. 6 Tahun 2014 pasal I tentang Desa, yang menyatakan bahwa Desa adalah kesatuan masyarakat hukum yang memiliki batas wilayah yang berwenang untuk mengatur dan mengurus urusan pemerintahan, kepentingan masyarakat setempat berdasarkan prakarsa masyarakat, hak asal usul, dan/atau hak tradisional yang diakui dan dihormati dalam sistem pemerintahan Negara Kesatuan Republik Indonesia. Dengan kedudukannya tersebut, pemerintah Desa berupaya melakukan pembenahan menuju arah kemandirian desa. Pasal 215 ayat (I) Undang-Undang No.32 Tahun 2004 secara tegas menyebutkan bahwa pembangunan kawasan pedesaan yang dilakukan oleh kabupaten/kota dan atau pihak ketiga, harus mengikut sertakan pemerintah desa dan badan permusyawaratan desa. Desa menurut

H.A.W. Widjaja dalam bukunya yang berjudul "Otonomi Desa" menyatakan bahwa "Desa adalah sebagai kesatuan masyarakat hukum yang mempunyai susunan asli berdasarkan hak asal-usul yang bersifat istimewa. Landasan pemikiran dalam mengenai

Pemerintahan Desa adalah keanekaragaman, partisipasi, otonomi asli, demokratisasi dan pemberdayaan masyarakat" (Widjaja, 2003: 3).
Ditinjau dari sudut pandang bidang ekonomi, desa berfungsi sebagai lumbung bahan mentah (raw material) dan tenaga kerja (man power) yang tidak kecil artinya. Desa- desa di Jawa banyak berfungsi sebagai desa agraris yang menunjukkan perkembangan baru, yaitu timbulnya industri-industri kecil di daerah pedesaan yang merupakan "rural industries".

Sejak tahun 2015 pembangunan desa menjadi fokus utama pembangunan daerah. Bergulirnya Dana Desa yang langsung diambil dari Anggran Pendapatan Belanja Negara (APBN) merupakan salah satu upaya untuk pembangunan desa. Dana Desa disusun untuk memberikan status hukum yang lebih kuat bagi desa dan memastikan alokasi anggaran pembangunan tahunan. Pada tahun 2015 Alokasi dana Desa sebesar Rp 20,76 Triliun, 2016 sebesar Rp 46,98 Triliun, 2017 dan tahun 2018 meningkat menjadi Rp 60 Triliun, dan 2019 meningkat lagi menjadi Rp 70 Triliun.. Peningkatan jumlah alokasi dana pada APBN-P yang ditransfer sejalan dengan visi pemerintah untuk "Membangun Indonesia dari Pinggiran dalam Kerangka Negara Kesatuan Republik Indonesia (NKRI)". Terjadinya peningkatan pemerataan pembangunan kesejahteraan desa merupakan harapan pengalokasian dana desa tersebut, yang dapat dilakukan melalui meningkatan pelayanan publik di desa, memajukan perekonomian di desa, mengatasi kesenjangan pembangunan antar desa dan memperkuat masyarakat desa sebagai subjek dari pembangunan daerah. Pada tahun 2018 pemerintah Desa Kanamit Barat telah berhasil mengimplementasikan program Pembangunan dan Pemberdayaan masyarakat dengan menggunakan Dana Desa sebesar Rp. 787.190.000 namun dalam realisasinya memiliki banyak permasalahan salah satunya ialah pembuatan Rencana Anggaran biaya Pembangunan (RAP) yang dianggap mark up oleh pihak Inspektorat selaku pemeriksa penggunaan anggaran Dana di Desa selain itu adanya pembanguan yang ditangani oleh salah satu anggota Badan Permusyawaratan Desa (BPD) dan Kegiatan Permodalan kepada Badan Usaha Milik Desa (BUMDes) yang tidak melalui prosedur musyawarah. Dari beberapa masalah tersebut tentulah mendapat respon yang negative dari masyarakat sekitar, terutama menyangkut kegiatankegiatan yang diagendakan oleh pemerintah desa 
yang tanpa melalui jalur musyawarah desa, meskipun tidak terbukti demikian seringkali Kepala Desa beserta Perangkat Desa dianggap menyalah gunakan anggaran Dana Desa, bahkan tidak sedikit masyarakat yang mengatakan bahwa Aparatur pemerintah desa dianggap melakukan tindak pidana korupsi. Adapun menyangkut permasalahanpermasalahan ini tidak dapat pula disimpulkan bahwa ini 100 Persen kesalahan dari pemerintah desa, karena faktanya aparatur pemerintah desa memiliki Sumber Daya Manusia yang kurang memadai, meskipun ada beberapa yang berlatar belakang lulusan sarjana namun sarjana-sarjana ini masih belum memiliki skill yang cukup dikarenakan tidak memiliki pengalaman dalam administrasi

pemerintahan, di tambah lagi para sarjana- sarjana ini memiliki usia yang masih terhitung muda sehingga pendapat masukan dan saran mereka masih belum didengar oleh para generasi tua yang ada, selain permasalahan Sumber Daya Manusia masalah kurangnya bimbingan oleh pemerintah Kecamatan Kabupaten dan Provinsi terkait Dana Desa merupakan alasan tersendiri sehingga banyak Aparatur Desa yang mendapat masalah dilapangan saat merealisasikan Dana Desa.

Berdasarkan latar belakang tersebut maka peneliti sangat tertarik untuk melakukan penelitian di Desa Kanamit Barat terkait Realisasi Dana Desa pada tahun 2019 berdasarkan Permendes Nomor 16 Tahun 2018 tentang Prioritas Penggunaan Dana Desa tahun Anggaran 2019 dengan rumusan masalah sebagai berikut :

1. Bagaimana implementasi kebijakan Dana Desa (DD) dalam menunjang pembangunan di desa Kanamit Barat pada tahun 2019?

2. Bagaimana implementasi kebijakan Dana Desa (DD) dalam menunjang pemberdayaan masyarakat di desa Kanamit Barat pada tahun 2019 ?

\section{B. TINJAUAN PUSTAKA}

\section{Definisi Pelayanan Publik}

Menurut Kamus Besar Bahasa Indonesia, pelayanan memiliki 3 (tiga) makna, perihal atau cara melayani, usaha melayani kebutuhan orang lain dengan memperoleh imbalan (Uang), kemudahan yang diberikan sehubungan dengan jual beli barang atau jasa. Pengertian pelayanan (service) menurut American Marketing Association, seperti dikutip oleh Donald
(1984) dalam (Hardiyansyah, 20II : 10 -

I I) bahwa :

"Pelayanan pada dasaranya adalah merupakan kegiatan atau manfaat yang ditawarkan oleh satu pihak kepada pihak lain dan pada hakekatnya tidak berwujud serta tidak menghasilkan kepemilikan sesuatu, proses produksinya mungkin juga tidak dikaitkan dengan suatu produk fisik".

menurut Lovelock (199I) dalam (Hardiyansyah, 20II : 10 - II), "Public service adalah produk yang tidak berwujud, berlangsung sebentar dan dirasakan dan dialami”. Artinya Public service adalah produk yang diberikan oleh penyedia jasa kepada konsumen tidak seperti sebuah barang yang di perjual belikan, layanan dapat berupa kecakapan dalam memberikan penjelasan atau menjawab pertanyaan dan tindakan-tindakan lain yang bertujuan membantu seseorang yang sehingga tidak berbentuk yang kemudian bisa dimiliki, berlangsung sesaat atau tidak tahan lama, tetapi dialami dan dapat dirasakan oleh penerima layanan.

\section{Kebijakan Publik}

Meskipun memberikan pengertian kebijakan publik hanya memandang dari satu sudut saja (yakni pemerintah), namun apa yang diungkapkan oleh Thomas Dye telah memberikan nuansa terhadap pengertian kebijakan publik.

Barangkali semua memahami bahwa kebijakan sematamata bukan merupakan keinginan pemerintah, akan tetapi masyarakatpun juga memiliki "apa” yang dilakukan, "mengapa"

mereka melakukannya, dan "bagaimana" akibatnya.

Implementasi kebijakan pada dasarnya ialah cara pencapaian suatu kebijakan dalam mengimplementasi kebijakan publik ada dua pilihan yaitu langsung mengimplementasikan dalam bentuk program atau melalui formulasi kebijakan derivat atau turunan dari kebijakan publik tersebut. Bicara tentang konsep implementasi kebijakan banyak ilmuan yang mengemukakan salah satunya pelaksanaan kebijakan yang di kemukaan Winarno (2014:177)

Metter dan Horn (1975: 6) juga mendefinisikan "implementasi kebijakan sebagai tindakan yang dilakukan oleh publik maupun swasta baik secara individu maupun kelompok yang ditujukan untuk mencapai tujuan yang telah ditetapkan dalam keputusan kebijakan". 
Mengenai hal ini Wahab (2002:59) menegaskan bahwa "Implementasi kebijakan merupakan aspek penting dari keseluruhan proses kebijakan". Oleh sebab itu tidak berlebihan jika dikatakan implementasi kebijakan merupakan aspek yang penting dari keseluruhan proses kebijakan.

\section{DESA}

Menurut Kamus Besar Bahasa Indonesia (KBBI) Desa merupakan kesatuan wilayah yang dihuni oleh sejumlah keluarga yang mempunyai sistem pemerintahan sendiri (dikepalai oleh kepala desa), kelompok rumah diluar kota yang merupakan kesatuan. Sedangkan Pedesaan merupakan daerah (kawasan) desa, daerah pemukiman penduduk yang sangat dipengaruhi oleh kondisi tanah, iklim, dan air sebagai syarat penting terwujudnya pola kehidupan agraris penduduk di tempat itu. Desa adalah suatu pemerintahan yang diberi hak otonomi adat, sehingga merupakan badan hukum dan menempati wilayah dengan batas-batas tertentu sebagai kesatuan masyarakat hukum yang berhak mengatur dan mengurus urusan masyarakat setempat berdasarkan asal usulnya. Wida (2016:I I).

Desa menurut H.A.W. Widjaja dalam bukunya yang berjudul "Otonomi Desa" menyatakan bahwa "Desa adalah sebagai kesatuan masyarakat hukum yang mempunyai susunan asli berdasarkan hak asal-usul yang bersifat istimewa. Landasan pemikiran dalam mengenai Pemerintahan Desa adalah keanekaragaman, partisipasi, otonomi asli, demokratisasi dan pemberdayaan masyarakat"

(Widjaja, 2003: 3).

"Desa adalah kesatuan masyarakat hukum yang memliki batas wilayah yang berwenang untuk mengatur dan mengurus urusan pemerintahan, kepentingan masyarakat setempat berdasarkan prakarsa masyarakat, hak asal usul, dan/atau hak tradisional yang diakui dan dihormati dalam sistem pemerintahan Negara Kesatuan Rrepublik Indonesia"

\section{DANA DESA}

Menurut UU No. 23 tahun 2014 pasal 294 ayat 3, Dana Desa dialokasikan oleh Pemerintah Pusat Untuk mendanai penyelenggaraan pemerintahan, pelaksanaan pembangunan, dan pembinaan kemasyarakatan, serta pemberdayaan masyarakat Desa sesuai dengan ketentuan undang-undang mengenai Desa. Dalam Permendes Nomor 16 Tahun
2018 Pasal I ayat 2 Dana Desa (DD) adalah dana yang bersumber dari APBN yang diperuntukkan bagi Desa dan ditransfer melalui APBD Kabupaten/Kota setiap tahun, untuk membiayai penyelenggaraan kewenangan Desa berdasarkan hak asal usul, dan kewenangan lokal skala Desa. (Sutoro, et.Al., 2016:7) Menurut Peraturan Menteri desa, pembangunan daerah tertinggal dan transmigrasi No. 21 tahun 2015, Dana Desa adalah dana yang bersumber dari Anggaran Pendapatan dan Belanja Negara yang diperuntukkan bagi Desa yang ditransfer melalui Anggaran Pendapatan dan Belanja Daerah kabupaten/kota dan digunakan untuk mendanai penyelenggaraan pemerintahan, pelaksanaan pembangunan, pembinaan kemasyarakatan, dan pemberdayaan masyarakat.

Sesuai dengan perintah UU N0. 6/2014 tentang Desa. Dana Desa disalurkan (ditransfer) ke rekening daerah dan tidak langsung ke rekening kas desa. Dana Desa disalurkan oleh Pemerintah kepada kabupaten/kota dengan cara pemindah- bukuan dari Rekening Kas Umum Negara (RKUN) ke Rekening Kas Umum Daerah (RKUD). Selanjutnya Dana Desa disalurkan oleh Kabupaten/Kota kepada Desa dengan cara pemindah bukuan dari RKUD ke rekening kas Desa paling lambat 7 (tujuh) hari kerja setelah diterima di kas Daerah.

\section{PEMBANGUNAN DAN PEMBERDAYAAN MASYARAKAT.}

Menurut Peraturan Menteri Desa, Pembangunan Daerah tertinggal, dan Transmigrasi (PERMENDES) No. 5 Tahun 2015, pembangunan Desa adalah upaya peningkatan kualitas hidup dan kehidupan untuk sebesar - besarnya kesejahteraan masyarakat Desa Menurut Suharto (2009:4) Pembangunan Kesejahteraan sosial adalah usaha yang terencana dan melembaga yang meliputi berbagai bentuk intervensi sosial dan pelayanan sosial untuk memenuhi kebutuhan manusia, mencegah dan mengatasi masalah sosial, serta memperkuat institusi-institusi sosial Menurut Permendes No. 5 tahun 2015 menyebutkan bahwa prioritas penggunaan dana desa tahun 2015 dialokasikan untuk tujuan pembangunan Desa yaitu meningkatkan kesejahteraan masyarakat Desa dan kualitas hidup manusia serta penanggulangan kemiskinaN melalui Pemenuhan Kebutuhan Dasar, Pembangunan Sarana dan Prasarana Desa, Pengembangan Ekonomi Lokal, 
Hambowo Sulistyo Putro \& Nurul Hikmah Kartini.. Implementasi Penggunaan Dana Desa Tahun Anggaran 2019 Berdasarkan Permendes Nomor 16 Tahun 2018 Tentang Priorotas Penggunaan Dana Desa Tahun 2019 Di Desa Kanamit Barat Kecamatan Maliku Kabupaten Pulang Pisau

Pemanfaatan Sumber Daya Alam dan Lingkungan, Menurut Peraturan Menteri desa, pembangunan daerah tertinggal dan transmigrasi No. 21 tahun 2015 menyebutkan bahwa Pemberdayaan Masyarakat Desa adalah upaya mengembangkan kemandirian dan kesejahteraan masyarakat dengan meningkatkan pengetahuan, sikap, keterampilan, perilaku, kemampuan, kesadaran, serta memanfaatkan sumber daya melalui penetapan kebijakan, program, kegiatan, dan pendampingan yang sesuai dengan esensi masalah dan prioritas

kebutuhan masyarakat Desa Pemberdayaan menurut Parsons, et. Al., dalam Suharto (2009:58) adalah proses dengan mana orang menjadi cukup kuat untuk berpartisipasi dalam, berbagai pengontrolan atas, dan mempengaruhi terhadap, kejadian-kejadian serta lembaga-lembaga yang mempengaruhi kehidupannya. Pemberdayaan menekankan bahwa orang memperoleh ketrampilan, pengetahuan, dan kekuasaan yang cukup untuk mempengaruhi kehidupannya dan kehidupan orang lain yang menjadi perhatiannya.

Menurut Peraturan Menteri desa, pembangunan daerah tertinggal dan transmigrasi No. 5 tahun 2015 menyebutkan bahwa Penggunaan Dana Desa tahun 2015 yang bersumber dari APBN untuk Pemberdayaan Masyarakat Desa terutama untuk penanggulangan kemiskinan dan peningkatan akses atas sumber daya ekonomi, sejalan dengan pencapaian target RPJM Desa dan RKP Desa setiap tahunnya, yang diantaranya dapat mencakup:

a. Peningkatan kualitas proses perencanaan Desa Mendukung kegiatan ekonomi baik yang dikembangkan oleh BUM Desa maupun oleh kelompok usaha masyarakat Desa lainnya

b. Pembentukan dan peningkatan kapasitas Kader Pemberdayaan Masyarakat Desa

C. Pengorganisasian melalui pembentukan dan fasilitasi paralegal untuk memberikan bantuan hukum kepada warga masyarakat Desa

d. Penyelenggaraan promosi kesehatan dan gerakan hidup bersih dan sehat

e. Dukungan terhadap kegiatan desa dan masyarakat pengelolaan Hutan Desa dan Hutan Kemasyarakatan

f. Peningkatan kapasitas kelompok.

\section{Indikator Pelaksanaan Dana Desa}

Banyak terdapat pengertian Indikator Pelaksanaan Dana Desa atau atau disebut, dapat didefinisikan bahwa :

a. Indikator Indikator Pelaksanaan Dana Desa sebagai nilai karakteristik tertentu yang digunakan untuk mengukur output atau outcame suatu kegiatan yang diprogramkan menggunakan Dana Desa,

b. Sebagai alat ukur yang digunakan untuk menentukan keberhasilan pelaksanaan Perogram-program Desa yang pendanaannya menggunakan Dana Desa,

C. Sebagai ukuran kuantitatif dan kualitatif yang menggambarkan pencapaian suatu sasaran atau tujuan yang telah ditetapkan oleh Pemerintah Desa,

d. Suatu informasi operasional yang berupa indikasi mengenanai pelaksanaan kegiatan atau kondisi fasilitas atau kelompok fasilitas. Sebenarnya indikator merupakan alat yang digunakan untuk menjelaskan suatu kondisi tertentu. misalnya suatu kondisi hasil pekerjaan dikatakana bagus, apa yang digunakan untuk menjelaskan hal yang disebut bagus. Apabila dikatakan seseorang sudah paham apa yang digunakan untuk menjelaskan mengenai tingkat pemahaman orang tersebut, paham yang bagaimana dan sejauh mana.

Dalam Permendes No 16 Tahun 2018 Tentang Prioritas Dana Desa Tahun 2019 ukuran Indikator Penggunaan Dana Desa

Secara Garis Besar dikelompokkan ke-dalam enam kategori, namun demikian, organisasi tertentu dapat mengembangkan kategori masing-masing yang sesuai dengan kebutuhannya, yaitu:

a. Berdasarkan Asas Musyawarah, Dalam Kamus Besar Bahasa Indonesia, musyawarah diartikan sebagai: pembahasan bersama dengan maksud mencapai keputusan atas penyelesaian masalah bersama. Selain itu dipakai juga kata musyawarah yang berarti berunding dan berembuk. Dalam penggunaan Dana Desa, maka proses yang harus dilakukan terlebih dahuli ialah mengadakan forum diskusi atau musyawarah antara Pemerintah Desa dengan Badan Permusyawaratan Desa (BPD) diikuti oleh tokoh-tokoh masyarakat sebagai mana tercantum dalam Permendes Nomor 16 Tahun 2018 tentang prioritas penggunaan Dana Desa pada Pasal 16 ayat I Prioritas penggunaan Dana Desa yang ditetapkan sebagai prioritas kegiatan, 
anggaran dan belanja Desa wajib dibahas dan disepakati melalui Musyawarah Desa.

b. Proyek terencana dalam RPJMDes, RKPDes dan APDes Dalam Permendes Nomor 16 Tahun 2018 tentang prioritas penggunaan Dana Desa pada Pasal 15 ayat 2 dan pasal 17 dalam hal pembangunan harus melalui peroses perncanaan Desa perencanaan tersebut di bukukan dalam RPJMDes, RKPDes dan APDes dan berdasarkan hal tersebut segala program yang telah dilaksanakan harus tertungan dalam RPJMDes, RKPDes dan APDes

C. Berdasarkan Tipologi Desa/Perkembangan Desa, dalam Permendes Nomor 16 Tahun 2018 tentang prioritas penggunaan Dana Desa pada Pasal 9 ada 3 (tiga) kategori dalam menentukan tingkat perkembangan desa Pertama Desa Tertinggal, Kedua Desa Berkembang, dan yang ketiga Desa Maju. Desa dalam penetapan prioritas penggunaan Dana Desa, harus mempertimbangkan tipologi Desa tersebut berdasarkan tingkat perkembangan Desa, karena penetapannya tingkatan perkembangan desa tersebut memiliki ketentuan-ketentuan khusus dalam pengalokasian Dana Desa tersebut terutama prioritas dalam pembanguanan sarana dan prasarana yang ada di desa (Desa Kanamit Barat pada tahun 2019 melalui Evaluasi Perkembangan Desa/Kelurahan oleh Kementrian Dalam Negri berada pada Desa Berkembang)

d. Hanya Untuk Bidang Pembangunan dan Pemberdayaan Masyarakat pada dasarnya Desa memiliki Lima Bidang Kegiatan yang didanai oleh Pemerintah Desa, yaitu Bidang Pemerintahan, Pembangunan, Pembinaan Masyarakat, Pemberdayaan Masyarakat dan Kegiatan Darurat Tanggap Bencana, namun dalam realisasinya ada ketentuan khusus dalam penggunaan Dana Desa, pada Permendes Nomor 16 Tahun 2018 tentang prioritas penggunaan Dana Desa pada Pasal 4 ayat I Penggunaan Dana Desa diprioritaskan untuk membiayai pelaksanaan dan kegiatan di Bidang Pembangunan dan Pemberdayaan Masyarakat Desa, adapun Pembanguanan yang dimaksud ialah pembangunan berupa infrastruktur, Sumberdaya Alam dan Sumber Daya Manusia dan sedangkan bidang Pemberdayaan Masyrakat ialah segala hal kegiatan yang bertujuan antuk meningkatakan ketahan pangan dan Ekonomi yang ada di masyarakat Desa.

e. Melaksanakan Pola Padat Karya Tunai, umumnya mayoritas masyarakat di desa berprofesi sebagai petani pekebun dan nelayan namun selain berprofesi sebagai petani pekebun dan nelayan tidak sedikit diantara mereka juga memiliki keahlian sebagai Tukang dan buruh bangunan dan maksud dari Pola Padat Karya Tunai ini ialah memberdayakan masyarakat yang ada dalam melaksanakan pembangunan yang ada di desa dalam Permendes Nomor

16 Tahun 2018 tentang prioritas penggunaan Dana Desa pada Pasal 8 ayat

I pola padat karya tunai menjadi keharusan dalam melaksanakan pembangunan yang ada di Desa dan kebijakan ini juga bertujuan sebagai Penanggulangan kemiskinan di Desa dengan membuka lapangan pekerjaan bagi masyarakat desa yang menganggur, setengah menganggur, keluarga miskin.

f. Transparansi/ Melakukan Publikasi, seseuai dengan Permendes Nomor 16 Tahun 2018 tentang prioritas penggunaan Dana Desa pada Pasal I3 ayat I lalah sebuah Kewajiban Pemerintah Desa untuk melakukan penyampaian kepada masayarakat tentang penggunaan Dana Desa tentang Program/Kegiatan apa saja yang telah akan/telah dilaksanakan pada tahun Tersebut, Biasanya penyampaian tersebut bisa dilakukan melalui sosialisasi kepada masyarakat melalui rapat terbuka dan diwajibkan pula menempel/Memasang Baliho.

\section{METODE PENEITIAN}

\section{Pendekatan Penelitian}

Penelitian atau penyelidikan adalah suatu tindakan yang dilakukan dengan sistematis dan teliti, dengan tujuan mendapatkan pengetahuan baru atau mendapatkan susunan dan tafsiran yang baru dari pengetahuan yang telah ada, dimana sikap orang yang bertindak itu harus kritis dan prosedur yang digunakan harus lengkap (Danil, 2004:5). penelitian kualitatif adalah penelitian yang temuan-temuannya tidak diperoleh melalui prosedur statistik atau bentuk hitungan lainnya. Penelitian kualitatif bisa dilakukan oleh peneliti dibidang ilmu sosial dan perilaku, juga oleh para peneliti dibidang yang 
Hambowo Sulistyo Putro \& Nurul Hikmah Kartini.. Implementasi Penggunaan Dana Desa Tahun Anggaran 2019 Berdasarkan Permendes Nomor 16 Tahun 2018 Tentang Priorotas Penggunaan Dana Desa Tahun 2019 Di Desa Kanamit Barat Kecamatan Maliku Kabupaten Pulang Pisau

menyoroti masalah yang terkait dengan perilaku dan peranan manusia. Penggunaan metode kualitatif bertujuan untuk memberikan informasi tentang situasi yang sedang terjadi dan hal-hal yang menyebabkan sesuatu dapat terjadi. (Robandi, 2008:120).

\section{Tempat dan Waktu Penelitian}

Penelitian tentang "Implementasi Penggunaan Dana Desa Tahun Anggaran 2019 Berdasarkan Permendes Nomor 16 Tahun 2018 Tentang Priorotas Penggunaan Dana Desa Tahun 2019". Lokasi penelitian berada di Di Desa Kanamit Barat Kecamatan Maliku Kabupaten Pulang Pisau. Waktu yang digunakan dalam proses penelitian adalahselama 3 Bulan Terhitung Sejak Bulan Januari Tahun 2020 s/d Bulan Maret Tahun 2020.

\section{Metode Pengumpulan Data}

Data dalam penelitian ini dikumpulkan dengan teknik obesrvasi (pengamatan), dokumentasi dan wawancara dengan Kepala Desa Kanamit Barat serta Perangkat Desa Kanamit Barat, Badan Permusyawaratan Desa, Lembaga Kemasyarakatan di Desa, target group, dan non-target group yang relevan dengan masalah penelitian. Adapun data yang digunakan dalam penelitian ini adalah data primer dan sekunder, pengumpulan data dilakukan melalui teknik :

1. Observasi (pengamatan) dilakukan untuk memperoleh data primer. Observasi dalam penelitian ini meliputi data tentang kondisi fisik bangunan dan hasil kegiatan Pembangunan dan pemberdayaan yang didanai oleh Dana Desa.

2. Dokumentasi dilakukan untuk memperoleh data sekunder yakni dengan cara menelihat bukubuku kepustakaan yang dikumpulkan dari berbagai dokumen seperti Perundang-undangan, arsip desa, laporan APBDes dan dokumen lainnya yang memuat pendapat para ahli sesuai dengan penggunaan Dana Desa.

3. Wawancara dilakukan untuk memperoleh data primer yakni dengan melakukan wawancara kepada informan yang telah ditetapkan oleh penulis sebelumnya secara mendalam dan terstruktur mengenai Dana Desa Dalam penelitian ini penulis menggunakan metode wawancara mendalam (in-depth interview). Menurut Bungin (2007:III) wawancara mendalam adalah proses memperoleh keterangan untuk tujuan penelitian dengan cara tanya jawab sambil bertatap muka antara pewawancara dan informan atau orang yang diwawancarai, dengan atau tanpa menggunakan pedoman (guide) wawancara, dimana pewawancara dan informan terlibat kehidupan sosial yang relatif lama.

\section{HASIL PENELITIAN DAN PEMBAHASAN.}

pagu yang telah diberikan oleh pemerintah pusat dan disesuaikan oleh pemerintah Kabupaten Pulang Pisau berdasarkan pertimbangan Luas wilayah, Jumlah Penduduk dan Tingkat Perkembangan Desa, Desa Kanamit Barat mendapat nilah pagu Dana Desa sebesar Rp. 923.564.000 jauh lebih besar dari pada tahun 2018 sebelumnya yang hanya Rp. 787.190.000.

kemudian dalam hal kegiatan dapat dilihat bahwa Desa Kanamit Barat menganggarkan untuk Bidang kegiatan Pembangunan dan Pemberdayaan Masyarakat dengan nominal di atas Seratus Juta ada Lima Kegiatan, Anggran kegiatan sama dengan atau di atas Lima Puluh Juta ada Dua Kegiatan dan Sembilan Kegiatan dengan Anggaran di bawah Lima Puluh Juta. Pemerintah Desa Kanamit Barat dapat dikatakan berhasil dalam merealisasikan penggunaan Dana Desa Tahun Anggaran 2019 apabila dalam penggunaan Dana Desa tidak mendapat masalah sosial dilapangan, mendapat respon yang positive dari sebagian besar masyarakat Desa dan tentunya telah memenuhi ketentuan-ketentuan yang telah ditetapkan melalui Peraturan Menteri Desa Nomor 14 Tahun 2018 tentang Perioritas Penggunaan Dana Desa Tahun Anggaran 2019 adapun ketentuanketentuan yang dimaksud ialah antara lain :

\section{Berdasarkan Asas Musyawarah Desa}

Musyawarah Desa yang dimaksud di sini ialah musyawarah yang di selenggarakan oleh pemerintah Desa baik oleh Kepala Desa maupun Badan Permusyawaratan Desa (BPD) dimana dengan maksud dan tujuan untuk merencanakan programprogram kegiatan yang di Danai oleh Dana Desa pada tahun 2019.

Berdasarkan dari wawancara dan penjelasan Pemangku Kebijakan (Kepala Desa dan BPD), Pelaksana Kegiatan yang merupakan Perangkat Desa, dan Kesaksian Masyarakat dapat disimpukan 
bahwa Pemerintah Desa Kanamit telah melaksanakan kegiatan Musyawarah Desa sebelum menetapkan segala kegiatan Desa dan dalam pelaksanaannya pemerintah Desa Kanamit Barat mengundang masyarakat Desa melalui tokoh-tokoh masyarakat, segala usulan dan masukan dari masyarakat melaliu tokoh masyarakat kemudian ditampung oleh pemerintah Desa Kanamit Barat yang kemudian di bahas kembali dalam rapat internal Pemerintah Desa dengan Badan Permusyawaratan Desa kemudian ditentukan sekala perioritasnya sebelum ditetapkan kegiatannya. Kegiatan Terencana Dalam RPJMDesa, RKPDesa dan APBDesa

Dalam penetapan kegiatan-kegiatan di Desa hal yang tidak boleh terlewatkan ialah peroses perencanaan Desa, dan peroses perencanaan desa inilah yang menjadi Dasar boleh tidaknya tersalurkan kegiatan-kegiatan Desa terutama kegiatan yang menggunakan Dana Desa. dan perencanaan tersebut tertuang dalam kitap Perencanaan Desa yaitu Rencana Pembangunan Jangka Menengah Desa (RPJMDesa), Rencana Kerja Pemerintah Desa (RKPDesa) Tahun Anggaran 2019 dan Anggaran Pendapatan dan Belanja Desa (APBDesa) Tahun Anggaran 2019 dan berdasakan ketiga hal tersebut barulah kegiatan-kegiatan Desa terutama Kegiatan yang menggunakan Dana Desa boleh direalisasikan.

Berdasarkan wawancara terhadap Pemangku Kebijakan (Kepala Desa dan BPD) dan Kepala Urusan Perencanaan Desa peneliti dapat menyimpulkan bahwa Pemerintah Desa Kanamit Barat dalam melaknakan kegiatan-kegiatan Desa terutama kegiatan Desa yang menggunakan Dana Desa Tahun 2019 selalu berpedoman pada kitap Perencanaan Desa yaitu RPJMDesa, RKPDesa dan APBDesa.

\section{Berdasarkan Tipologi I Perkembangan Desa}

Tipologi/perkembangan desa ialah suatu kondisi tingkat perkembangan desa, dalam Peraturan Peraturan Menteri Desa ada tingkatan perkembangan Desa : Desa Tertinggal, Desa Berkembang dan Desa Tertinggal, dan dalam konteks perkembangan Desa, Desa Kanamit Barat pada tahun 2019 oleh penilaian pemerintah Daerah Kabupaten Pulang Pisau memiliki katagori Desa Berkembang yang mana dalam penggunaan Dana Desa berdasarkan Peraturan
Menteri Desa Nomor 16 Tahun 2018 tentang perioritas penggunaan Dana Desa Tahun 2019 pasal 9 poin b ialah memperioritaskan :

a. pembangunan, pengembangan dan pemeliharaan infrastruktur ekonomi serta pengadaan sarana prasarana produksi, distribusi dan pemasaran untuk mendukung penguatan usaha ekonomi pertanian berskala produktif, usaha ekonomi untuk ketahanan pangan dan usaha ekonomi lainnya yang difokuskan kepada pembentukan dan pengembangan produk unggulan Desa dan/atau produk unggulan kawasan perdesaan;

b. pengadaan sarana prasarana sosial dasar dan lingkungan yang diarahkan pada upaya mendukung pemenuhan akses masyarakat Desa terhadap pelayanan sosial dasar dan lingkungan; dan pengembangan dan pemeliharaan infrastruktur dasar.

Dari wawancara kepada pemangku kebijakan di atas (Kepala Desa dan BPD) dan apabila peneliti meninjau kembali APBDesa peneliti dapat menyimpulkan bahwa dalam Penggunaan Dana Desa Tahun 2019 Pemerintah Desa Kanamit Barat secara garis besar telah memenuhi aspek-aspek kegiatan pembangunan dan pemberdayaan masyarakat berdasarkan Tipologi/Perkembangan Desa. Dana Desa Hanya Dianggarkan untuk Bidang Pembangunan dan

Pemberdayaan Masyarakat.

Dalam penggunaan Anggran Desa yang telah diberikan oleh pihak Kabupaten berbentuk Alokasi Dana Desa Dari Pemerintah Pusat Dana Desa, dan pendapatan lain-lain yang sah seperti Pendapatan Asli Desa, Bagi Hasil Pajak dan lain-lain pada dasarnya pemerintah Desa Kanamit Barat memliki beberapa Bidang Kegiatan yang dapat di Danai oleh Anggaran Pendapatan dan Belanja Desa, seperti Bidang Pemerintahan, Pembangunan, Pembinaan Masyarakat, Pemberdayaan Masyarakat dan terakhir Keadaan Darurat Tanggap Bencana, terkusus dalam penggunaan Dana Desa sudah menjadi ketentuan dalam Peraturan Menteri Desa bahwa penggunaan Dana Desa hanya diperbolehkan untuk Bidang Pembangunan dan Pemberdayaan Masyarakat.
3. Dalam
Pelaksanaan
Kegiatan
Pembangunan
Masyarakat
dan
Harus 
Hambowo Sulistyo Putro \& Nurul Hikmah Kartini.. Implementasi Penggunaan Dana Desa Tahun Anggaran 2019 Berdasarkan Permendes Nomor 16 Tahun 2018 Tentang Priorotas Penggunaan Dana Desa Tahun 2019 Di Desa Kanamit Barat Kecamatan Maliku Kabupaten Pulang Pisau

\section{menggunkan Pola Padat Karya Tunai}

Menggunakan Pola Kegiatan Padat Karya Tunai dalam Peraturan Menteri Desa artinya dalam kegiatankegiatan Desa baik itu Pembangunan dan Pemberdayaan harus memberdayakan masyarakat local Desa, baik dari pemegang peroyek, Tukang, sampai Buruh Bangunannya.

Berdasarkan wawancara terhadap Pemangku Kebijakan (Kepala Desa dan BPD

), Pelaksana Kegiatan ( Perangkat Desa ) dan kesaksian Perwakilan Masyarakat (Kepala Dusun Sidodadi dan Sidomulyo) peneliti dapat menyipulkan bahwa kegiatan-kegiatan Desa 2019 yang menggunakan Dana Desa sebagian besar memang telah menggunakan pola Padat Karya Tunai dalam pengerjaannya namun tidak dapat dipungkiri ada I kegiatan yang tidak menggunakan pola Padat Karya Tunai yaitu pendirian Tower mini BTS untuk internet Desa, namun dari sudut pandang peneliti hal tersebut wajar saja terjadi dikarenakan kurangnya pengetahuan dan keterampian dari warga Desa Kanamit Barat untuk kegiatan tersebut sehingga mau tidak mau pemerintah Desa Kanamit Barat harus menggunakan jasa dari orang luar Desa untuk pengerjaan peroyek tersebut.

\section{Kegiatan Bersifat Transparan}

Yang dimaksud dengan Transparan ialah pemerintah Desa Kanmit Barat harus terbuka kepada masyarakat atas segala kegiatan- kegiatan di Desa dan hal tersebut diwujudkan dengan adanya sosialisasi langsung kepada masyarakat terkait kegiatan-kegiatan Desa pada Tahun 2019 melalui forum penetapan Anggaran Pendapatan dan Belanja Desa (APBDesa) Tahun Anggaran 2019, kemudian memasang Baliho tentang rincian APBDesa dan terakhir memasang Pelang Papan Peroyek di setiap kegiatan berbentuk pembangunan Desa.

Berdasarkan wawancara terhadap Pemangku Kebijakan (Kepala Desa dan BPD), Pelaksana Kegiatan (Perangkat Desa Kanamit Barat) dan Kepala Dusun Sidodadi dan Sidomulyo selaku Perwakilan Masyarakat Peneliti dapat menyimpulkan bahwa Pemerintah Desa Kanamit Barat telah

Transparan dalam penggunaan Dana Desa Tahun 2019 itu terbukti dari keterangan Narasumber di atas Pemerintah Desa Kanamit Barat telah mengundang masyarakat terkait penetapan Anggaran
Pendapatan dan Belanja Desa kemudian adanya pemasangan Baliho Rincian Penggunaan Anggaran Pendapatan dan Belanja Desa dan terakhir telah dilaksanakannya pemasangan papan pelang peroyek disetiap kegiatan yang berhubungan dengan adanya pembangunan di Desa Kanamit Barat.

\section{E. KESIMPULAN DAN SARAN}

1. Kesimpulan

Berdasarkan uraian hasil Penelitian dan pembahasan yang telah diuraikan pada bab sebelumnya, maka dalam penulisan ini dapat ditarik kesimpulan sebagai berikut :

1. Penggunaan Dana Desa Tahun Anggaran 2019 di Desa Kanamit Barat Kecamatan Maliku Kebupaten Pulang Pisau untuk Bidang Pembangunan Desa sebagian besar telah sesuai dengan ketentuan Peraturan Menteri Desa Nomor 16 Tahun 2018 tentang Perioritas Penggunaan Dana Desa Tahun Anggaran 2019 dan ada satu yang kurang sesuai dikarenakan tidak menggunkan Pola Padat Karya Tunai di mana Perogram tersebut adalah program pembangunan Mini Tower BTS untuk Internet Desa dan ada dua Kegiatan yang menggunakan Dana Desa tidak terlaksana yaitu Perbaikan Lapangan Sepak Bola dan Pelatihan Pertanian.

2. Penggunaan Dana Desa Tahun Anggaran 2019 di Desa Kanamit Barat Kecamatan Maliku Kabupaten Pulang Pisau untuk Bidang Pemberdayaan Masyarakat seluruhnya telah sesuai dengan ketentuan Peraturan Menteri Desa Nomor 16 Tahun 2018 tentang Perioritas Penggunaan Dana Desa Tahun Anggaran 2019.

\section{Saran-saran}

Saran-saran yang dapat penulis sampaikan ialah sebagai berikut :

a. Kepada Kepala Desa dan Badan Permusyawaratan Desa msekipun dalam Realisasi Penggunaan Dana Desa Tahun Anggaran 2019 sudah masuk kategori terlaksana dengan sangat baik, dikarenakan aturan selalu berkembang dan beubah-ubah disetiap tahunnya diharapkan Kepala Desa dan Badan Permusyawaratan Desa untuk terus mencari informasi dan tidak bosanbosan mempelajari aturan- atuaran yang telah ditetapkan oleh pemerintah pusat maupun 
daerah.

a. Kepada Kepala Desa Kanamit Barat, untuk terus mengawasi kinerja Perangkat desanya dikarenakan peneliti melihat meskipun kinerja perangkat Desa Kanamit Barat pada Tahun 2019 dalam Pelaksanaan Kegiatan sangatlah baik, namun tanpa ada pengawasan yang dilakukan dan ketegasan dari Kepala Desa maka bukan hal yang tidak mungkin kinerja yang baik tersebut akan menurun kualitasnya ditahun-tahun berikutnya, kemudian dalam hal kebijakan peneliti melihat Pemerintah Desa Kanamit Barat dalam menggukan Dana Desa Tahun 2019 terlalu berfokus terhadap pembangunan Infrastruktur karena peneliti menganggap pada dasarnya infrastruktur jika hanya untuk kegiatan keseharian warga tanpa ada nilai Ekonomi disitu maka hanya akan bernilai estetika saja dan tak ada manfaat jangka panjang untuk warga Desa Kanamit Barat sedangkan kita semua tau kalau setiap harinya sampai bertahun-tahun kemudian infrastruktur pasti akan mengalami kerusakan yang artinya jika pemerintah Desa Kanamit Barat hanya memperioritaskan dibidang itu maka tidak akan pernah ada habisnya, jadi menurut peneliti untuk tahun-tahun berikutnya Pemerintah Desa Kanamit Barat harus sudah mulai membangun Sumber Daya Manusia, memperbanyak program Pemberdayaan masyarakat dan menumbuh kembangkan dari potensi- potensi yang ada di Desa Kanamit Barat, karena pada dasarnya tidak ada kepastian bahwa Dana Desa akan terus diberikan kepada Desa-desa yang ada di

\section{DAFTAR PUSTAKA}

Abdul Wahab, Solichin."Analisis Kebijaksanaan: dari Formulasi ke Implementasi Kebijaksanaan Negara”. Jakarta : Sinar Grafika. 2018.

Herdiyansyah. 20II. Kualitas Pelayanan Publik. Yogyakarta : Penerbit Gava Media.

Hj. Rulinawaty Kasmad, "Studi Implementasi Kebijakan Publik". Univesitas Makasar : Penerbit Pustaka Belajar. 2018.

Muhammad Instan."Implementasi Dana Desa di Desa Air Meles Bawah Kecamatan Curup seluruh Indonesia, jadi jika Pemerintah Desa Kanamit Barat telah membangun Sumber Daya Manusia, memperbanyak Perogram Pemberdayaan Masyarakat dan menumbuh kembangkan Potensi yang ada di Desa Kanamit Barat sehingga terjadinya peningkatan Ekonomi bahkan meningkatkan kesejahteraan masyarakat dan Desa Kanamit Barat menjadi Desa Mandiri sehingga tidak lagi digunakan istilah "Membangun Desa Kanamit Barat" namun menjadi "Desa Kanamit Barat Membangun" setelah itu tidak akan ada kekhawatiran bagi pemerintah Desa Kanamit Barat jika sewaktu-waktu Perogram Dana Desa telah ditiadakan oleh Pemintah Pusat Kepada Perangkat Desa Kanamit Barat selaku Pelaksana Kegiatan meskipun hasil Peroyek yang telah dikerjakan telah memenuhi kriteria standar dalam pembangunan, namun peneliti melihat bahwa kualitas pembangunan yang saat ini masih bisa di tingkatkan kembali, khususnya dalam hal kerapian dalam hasil pembangunan.

b. Dan terakhir Kepada Masyarakat Desa Kanamit Barat, diharapkan untuk bisa lebih keritis lagi dalam memberikan usulan/pendapat saat mengikuti rapat-rapat atau musyawarah desa, dikarenakan peneliti melihat dalam penggunaan Dana Desa Tahun 2019 masih terlalu berfokus dalam bidang Infrastruktur saja dan untuk Pemberdayaan Desa masih Tergolong Sedikit, jadi diharapkan untuk tahun-tahun berikutnya masyarakat dapat memberikan masukan yang baik khususnya dalam hal peningkatan Keterampilan Masyarakat dan Ekonomi Desa.

Timur, Rejang Lebon, Bengkulu”. Jurnal. 2016.

R.Ahmadi."Metodoli Penelitian Kualitatif"'. Yogyakarta : Penerbit Ar-Ruzz Media. 2014

Sanantya Wida Habsari. "Proses Kebijakan Penataan Angkutan Umum di Kawasan Perkotaan Daerah Istimewa Yogyakarta". Yogyakarta. Skripsi. 2016 Samodra Wibawa."Politik Perumusan Kebijakan Publik”.Jakarta : Graha IImu. 
Hambowo Sulistyo Putro \& Nurul Hikmah Kartini.. Implementasi Penggunaan Dana Desa Tahun Anggaran 2019 Berdasarkan Permendes Nomor 16 Tahun 2018 Tentang Priorotas Penggunaan Dana Desa Tahun 2019 Di Desa Kanamit Barat Kecamatan Maliku Kabupaten Pulang Pisau

Ulber Silalahi. "Metode Penelitian Sosial". Bandung : Penerbit PT Refika Aditama. 2012

Winarsih, Atik Septi \& Ratminto. 2005. Manajemen Pelayanan. Universitas Muhamadiah. Yogyakarta : Penerbit Pustaka Pelajar. 2016.

Widjaja. "Otonomi Desa” : Penerbit Raja Grafindo Persada Divisi Rajawali Pers. 2010.

Profil Desa Gambut Desa Kanamit Barat 2019 Undang-Undang Nomor 6 Tahun 2014

tentang Desa

Peraturan Pemerintah Nomor 72 Tahun 2005 tentang Desa Permendagri Nomor 66 Tahun 2007 Tentang Perencanan Pembangunan Desa.

Peraturan Menteri Desa Nomor 16 Tahun 2018 tentang Prioritas Penggunaan Dana Desa 2019

Peraturan Menteri Dalam Negeri Nomor 13 Tahun 2006 Tentang Pedoman Pengelolaan Keuangan Daerah.

Permendagri Nomor 20 Tahun 2018 Tentang Pedoman Penggunaan Keuangan Desa

Undang-undang nomor 23 tahun 2014 tentang pemerintahan Daerah 